\title{
回転するポリゴンミラーまわりの流れ構造*
}

\author{
小原弘 道*1, 西村大志*2, 後藤 智 幸*3 \\ 金子好 司*4, 堀越 了*4, 松平晏 明*1
}

\section{Flow Structure Around a Rotating Polygon Mirror}

\author{
Hiromichi OBARA*5, Daishi NISHIMURA, Tomoyuki GOTO, \\ Koji KANEKO, Satoru HORIKOSHI and Yasuaki MATSUDAIRA \\ ${ }^{* 5}$ Department of Mechanical Syntem Engineering, Tokyo Metropolitan Institute of Technology, \\ 6-6 Asahigaoka, Hino-shi, Tokyo, 191-0065 Japan
}

\begin{abstract}
A polygon mirror is one of the important optical scanning components for a laser beam printer, a copy machine and so on. It has the serious troubles related to the fluid dynamic flow structures such as high frequency noise, frosted mirror and jittering of the rotating mirror under high rotating speed condition. The flow structures around the rotating polygon mirror were investigated by the flow visualization using a Particle Image Velocimetry and the velocity measurement using a Laser Doppler Velocimetry. As the results, significant flow structures were clarified and associated with these troubles. The first is the periodical fluctuating structure, which induces the high frequency noise, showing as a bow-shaped region and a pair of the vortex tubes. The second is an alternative flow structure shedding from near the polygon mirror, which is considered as one of the causes of the jittering. In addition, this flow accompanies the complicated three-dimensional vortices on the outskirts of the alternative flow structure. The third is the sinking flow structure toward the polygon mirror contributing the frosted mirror trouble.
\end{abstract}

Key Words: Flow Visualization, Flow Noise, Rotating Disk, Polygon Mirror, PIV, LDV

\section{1. 緒}

ポリゴンミラーはレーザプリンタやコピー機などに 必要不可欠なレーザ走査装置の重要な要素部品であ る. 近年, 高速印刷, 高精度印刷のためにポリゴンミ ラーの回転速度の高速化が図られる中で, いくつかの 克服すべき技術課題が生じてきている．その一つとし て, 高速回転化に伴い顕著化してきたポリゴンミラー の高周波騒音がある.この騒音は, 回転数とミラーの 角数の積に対応した卓越周波数を示す特性を有してお り, 軸受や基板の振動などの機械的な要因から生じる 騷音とは異なるものであり, 特に騒音レベルは回転速 度の増加に伴い急激に増加することから早急な解決が 望まれている。次に，ミラー性能の観点から，長時間 連続運転による鏡面の曇りの問題がある。これは環境 中に浮遊する物質が鏡面上の角部から辺上 $1 / 3$ を中心 とする局所的な領域に積層・凝着され量り領域を形成

* 原稿受付 2003 年 5 月 16 日.

*1 正員, 東京都立科学技術大学機械システム工学科( 1910065 日野市旭が丘 6-6).

*2 川崎重工業(株) ( 3650 -8680 神戸市中央区東川崎町 1-1-3).

*3 東京都立科学技術大学大学院工学研究科.

*4 富士写真光機 (株) (s330-8624 さいたま市北区植竹町 1324).

E-mail : obara@tmit.ac.jp
する現象であり，どのような形で浮遊物質が供給され 積層・凝着されるのか, この生成機構は明らかではな い. 最り領域は，ポリゴンミラーの鏡面の反射性能を 劣化させ, ポリゴンミラーュニットのメンテナンスコ ストの増大や製品寿命と直結する.さらに, 走査精度 の劣化につながる回転の不安定化の問題がある。これ は軸受の改良などの機械的な取組みにより解決が図ら れた部分もあるが, 明確な原因が不明なために，依然 として残された課題となっている. 以上のポリゴンミ ラーに関する技術課題に対して, 機械的な振動・騒音 特性などの観点からいくつかの研究(1)(2) はあるもの の, 流体力学的な観点からの研究 ${ }^{(3)}$ は低速回転域にお いてさえも, 知見する限りほとんどなされていない.

以上の背景のもとに本研究では, ポリゴンミラーま わりの流れの基礎的な知見を得るために, 低回転数域 において, ポリゴンミラー各断面における二次元 PIV 計測と LDV 計測を併用し, そのベクトルマップと速 度時間履歴を求める。これより, 回転円盤とポリゴン ミラーの流れ構造を比較検討し, 流体騒音, 鏡面の臺 りおよび回転むらの要因となるポリゴンミラー固有の 流れ構造を明らかにする.さらに，ポリゴンミラー近 傍部に形成される一対の渦管の立体構造も明らかにす る. 


\section{2. おもな記 号}

$d:$ ポリゴン内接円, 円盤直径

$R e$ :レイノルズ数 $=d / 2 \cdot(\Omega / \nu)^{1 / 2}$

$R e_{c}:$ 遷移レイノルズ数

$V:$ 面内合速度

$V_{d}$ : ポリゴン, 円盤外接円周速度

$V_{r}:$ 半径方向速度

$V_{\theta}:$ 周方向速度

$V_{z}:$ 軸方向速度

$\theta$ : ポリゴン角部からの回転角度 $\left(0 \sim 60^{\circ}\right)$

$\zeta:$ 無次元渦度 $=d / V_{d}\left\{\left(\partial V_{z} / \partial r\right)-\left(\partial V_{r} / \partial z\right)\right\}$

$\Omega$ :角速度

\section{3. 実験装置および実験方法}

図 1 にポリゴンミラー(以下，ポリゴンとする)なら びに円盤を収納する容器とモー夕制御部により構成さ れる実験装置を示す。容器は可視化観察のための三つ の透明アクリル空を有し, その中央にポリゴンおよび 円盤の回転軸が取付けられている、軸はパルスモータ で駆動されており，200 rpm から $3000 \mathrm{rpm}$ までの任 意の回転数範囲で安定して回転させることが可能であ る. PIV および LDV 計測用シーディング粒子とし て，噴霧したグリセリン水粒子を用いた。ポリゴン， 円盤ともに厚さ $6 \mathrm{~mm}$, 内接円直径 $d=40 \mathrm{~mm}$ を有 し, 計測用レーザシートの乱反射を防止するために鏡 面部も含め黒色の塗装がなされている.

PIV 計測システムは, 粒子画像取得のための CCD カメラ $(1008 \times 1018$ ピクセル, KODAK Megaplus

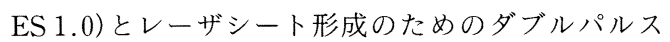
Nd: YAGレーザ(New wave research MINILASEI）およびシステムを制御し速度場情報を演算するコン ピュータ装置群(Dantec Flow Map, Gateway PC) か

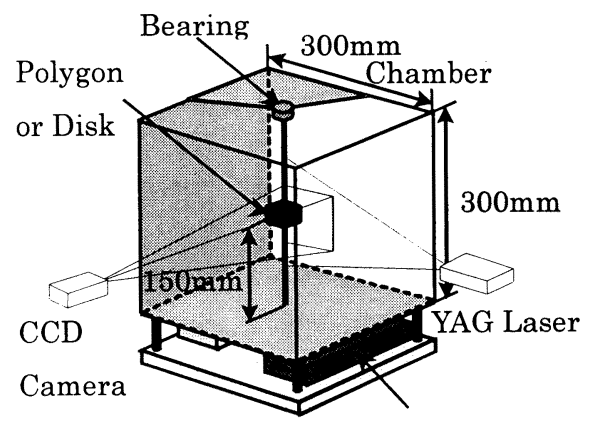

Rotating System

Fig. 1 Experimental apparatus
ら構成される。速度場情報は CCD カメラで撮影され た 2 枚の粒子画像から相互相関法を用いて取得した。 LDV 計測システムは, 2 方向流速を同時計測可能なプ ローブを含む光学系, ならびに解析装置(Dantec BSA）から構成されている.

ここで，ポリゴン外周の流れはポリゴン表面の境界 層の影響を受ける. 角速度 $\Omega$ と半径 $d / 2$ より定義さ れる円盤面上境界層の遷移レイノルズ数は $R e_{c}=$ 280〜 530(4)(5) である.これに対して, 実機ポリゴンの 内接円半径を用いたレイノルズ数 (回転数 $2500 \mathrm{rpm}$ ) は $R e=264$ であり, 円盤の $R e_{c}$ 以下の值であるが, ポリゴン角部やポリゴン周辺部品の影響を受けて, 実 機ではすでに境界層は乱流に遷移していると推測され る.図 2 は, 実機におけるポリゴンの有無による騒音 特性の差異を回転数と騒音の卓越周波数の関係により 示したもの(3)である。また, 併せて本実験装置におけ る回転数 $200 \mathrm{rpm}$ から $2000 \mathrm{rpm}$ までの LDV 計測の 予備実験から得た速度の卓越周波数特性を示す。ポリ ゴンの無い機械的な騒音のみの場合には，いずれの回 転数においても回転数と一致した卓越周波数を示して おり，この周波数は機械騒音とみることができる。一 方, ポリゴンがある場合には回転数の 6 倍の周波数, すなわちポリゴンの角数と回転数との積で表される周 波数に卓越周波数を有していること, および低回転数 域ではあるが LDVにより得られた速度も同一の卓越 周波数を得ていることから, この周波数は流体騒音と 関連づけられる.このことは, ポリゴン面上に形成さ

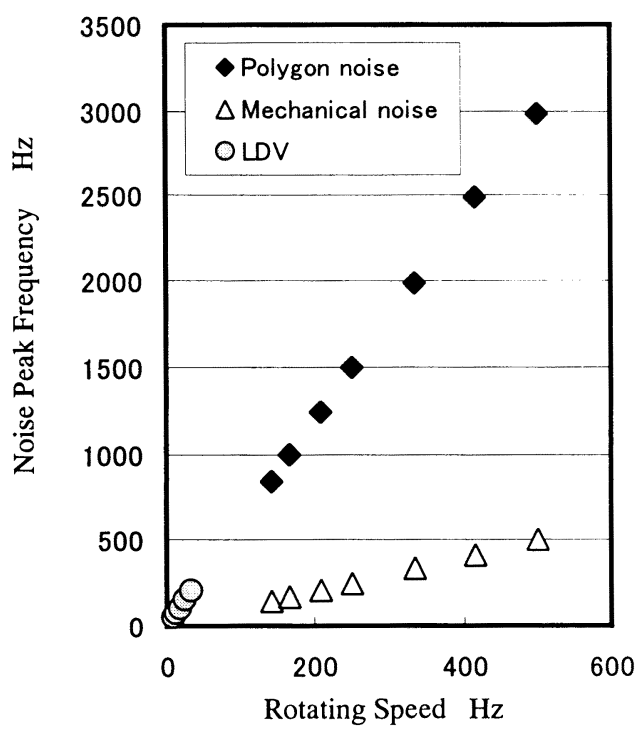

Fig. 2 Peak frequency of noise and velocity 


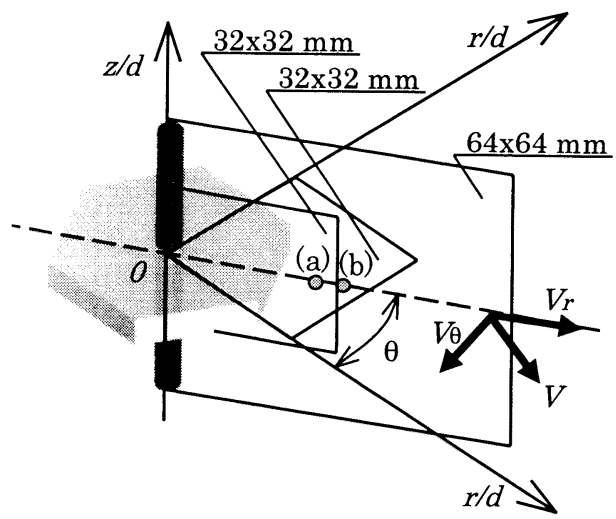

Fig. 3 Coordinate system and measurement planes

れる層流または乱流境界層にかかわらず，ポリゴン外 周の流れにおいて角部の存在により形成されるポリゴ ン固有の流れ構造が低回転数から高回転数に至る広い 回転数範囲で維持されていることを意味している。こ れより，本実験条件下ではポリゴン面上の境界層が実 機とは異なる層流であると予想されるが，ポリゴン固 有の流れ構造が支配的かつ明示できると考え, 500 $\operatorname{rpm}(R e=37)$ の低回転数域において PIV 計測を行っ た。

図 3 は座標系, PIV による計測断面およびLDVに よる計測点を示す，座標系は極座標を用い，原点はポ リゴン中心としたＰIV 計測においては，r-z断面に ついて $32 \times 32 \mathrm{~mm}(\Delta t=400 \mu \mathrm{s})$ および $64 \times 64 \mathrm{~mm}$ $(\Delta t=1000 \mu \mathrm{s})$ の領域, $r-\theta$ 断面については中央断面 の $z / d=0(\Delta t=300 \mu \mathrm{s})$ とポリゴン上面と同一面の $z / d=0.1(\Delta t=1500 \mu \mathrm{s})$ に打いて計測を行った。ここ に, $\Delta t$ は PIV 計測時の 2 枚の粒子画像取得時間間隔 であり，画角ごとに設定したＬDVによる計測は中 央断面上 $(z / d=0)$ の点 ( a ) $r / d=0.7$, 点 ( b ) $r / d=$ 0.8 で行った.

\section{4. 実験結果および考察}

4 ・1 円盤とポリゴンの比較 図 4 は回転円盤な らびにポリゴンまわりの $r-\theta$ 断面 $(z / d=0)$ 瞬間速度 ベクトルを示す. 図 4(a) 円盤では, 外周近傍の流れ は，円盤回転周速度の 70 $80 \%$ の周方向速度を有する 回転流を形成しており，円盤から離れるにしたがって 周方向のみならず半径方向速度も含む速度分布とな る.さらに, 半径方向へ向かうにつれて速度は減衰す る。これらの様相は, 図示を割愛しているが 50 枚の 計測データから算出された時間平均速度分布と同一の

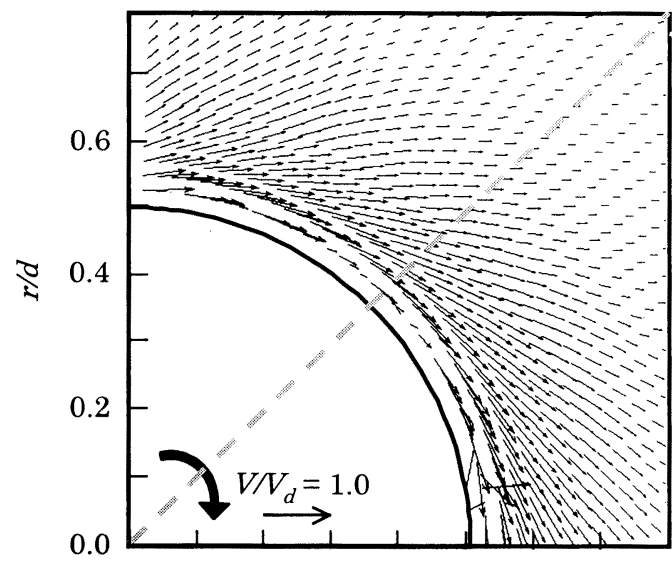

(a) Disk

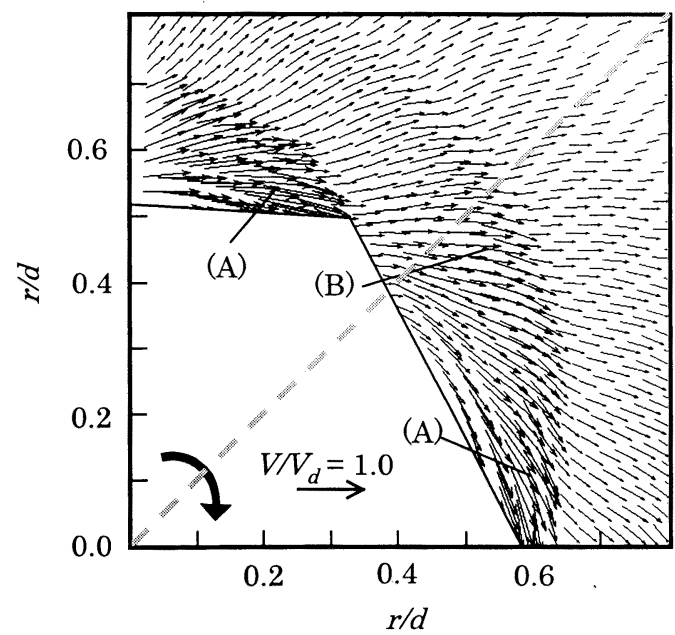

(b) Polygon

Fig. 4 Instantaneous velocity vector map $(r-\theta$ plane, $z / d=0)$

結果となっている.図 4(b)ポリゴンでは, 角部近傍 にポリゴン周速度 $V_{d}$ と同程度の周方向速度を有し, 周囲に比べて局所的に速い速度を示す領域 (A) が形成 されている.さらにポリゴンから少し離れた $r / d<$ 0.7 の領域においては，ポリゴン周速度 $V_{d}$ の $50 \%$ 程 度の半径方向速度を有する局所的に速度の速い領域 (B)が存在する.この領域 $(\mathrm{A})$ と（B)の間において は, 領域 (B)に向かうにつれて周方向速度が支配的な 流れから半径方向速度が支配的な流れへと徐々に変化 し, 回転方向上流側から下流側へと旋回しつつ弧状の 領域を形成している。なお，これらの領域はポリゴン の各辺に対応して存在し,この流れ構造は図 5 に示す 四角形など他の多角形においても，それぞれの角部の 角数に対応して形成される結果を得ている。これらの 


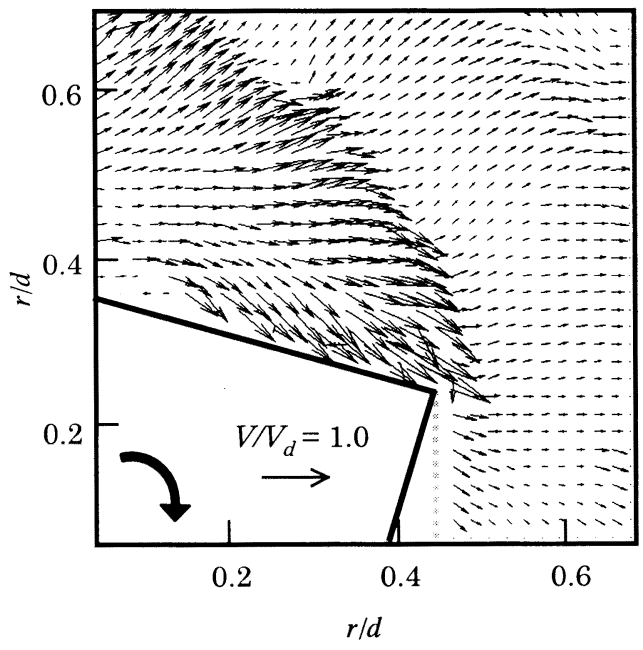

Fig. 5 Instantaneous velocity vector map (Square, $500 \mathrm{rpm}, r-\theta$ plane, $z / d=0$ )

事実から，角部の通過により形成される流れ構造であ るといえる，さらに，角数の増加によりそれぞれの構 造ごとの間隔が狭まり, 相互の干涉の効果が強く現れ てくると考元られる.

図 6 はポリゴンまわりの広い計測領域における $\theta$ 断面瞬間速度べクトルを示す。ここに, 図 4 (b) と 同一面の図 $6(\mathrm{a}) z / d=0$ と, ポリゴン上面と同一面 である図6(b) $z / d=0.1$ をそれぞれ示している.

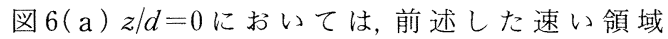
(A)・(B) で形成される弧状の領域のさらに外周側に 領域 $(\mathrm{A}) ・(\mathrm{~B})$ に比べ速度は小さいがポリゴン周速度 $V_{d}$ の 40\%程度の速度を有する局所的に速度の速い領 域 (C)が形成されている。これは, 回転方向一つ上流 側のポリゴン角部通過によって形成された弧状の領域 が旋回してきたものである.さらに, 外周側 $r / d>$ 0.8 に扔いては, いずれもポリゴン周速度 $V_{d}$ の $20 \%$ 程度の半径方向速度を有し, $r / d=1.3$ 付近に局所的 に遅い速度領域も現れている. 次に, 図 6(b) $z / d=$ 0.1 においては, ポリゴン極近傍には後述するポリゴ ン角部ごとに形成される鏡面側への流れが示されてい るものの, 最大でもポリゴン周速度 $V_{d}$ の $20 \%$ と $z / d=0$ 断面に比べ全領域にわたり小さい速度となっ ている.特に, $z / d=0$ において示された弧状の領域 が形成される $r / d<0.8$ の領域ではポリゴン周速度 $V_{d}$ の数\%の非常に低速度の領域となっている．この 領域の外周側 $r / d>0.8$ においては局所的に速い速度 領域や遅い速度領域がまだら状に現れる分布となって おり,この計測面を横断する速度 $V_{z}$ を含む三次元的

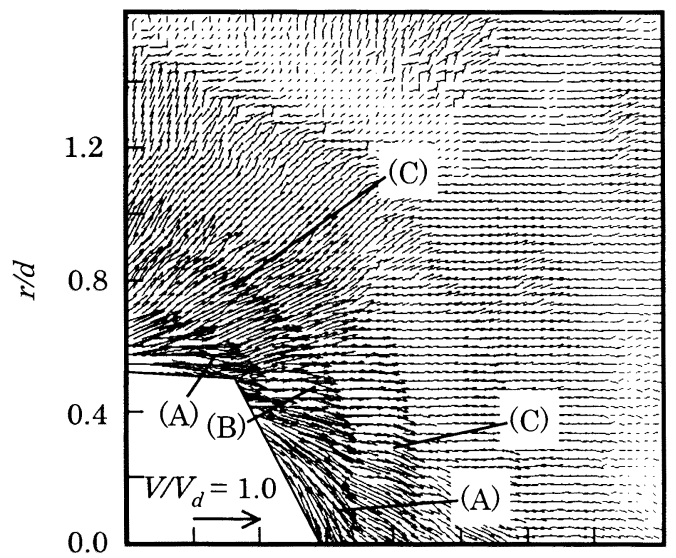

(a) $z / d=0$

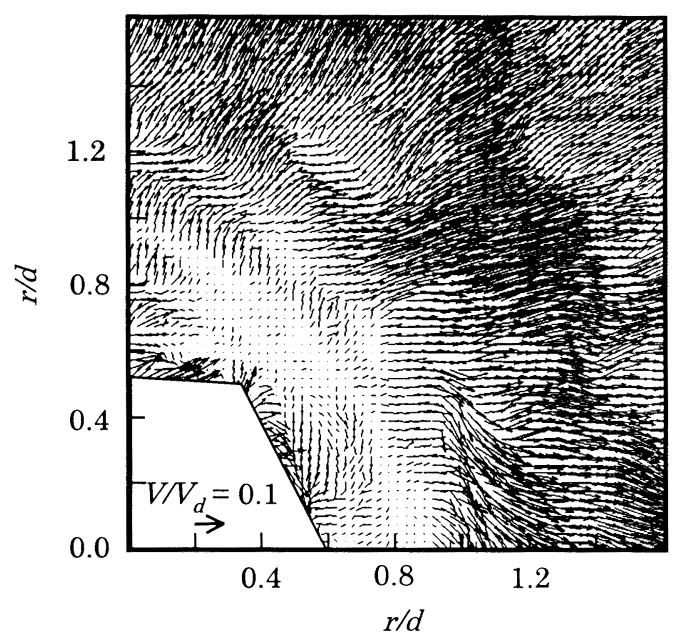

(b) $z / d=0.1$

Fig. 6 Instantaneous velocity vector map around the polygon $(r-\theta$ plane, wide view)

な流れ構造となっていると考えられる。な抢，他の瞬 間速度べクトル結果から，この三次元的な流れ構造は ポリゴン角部位置すなわち回転角度に無関係にさまざ まなまだら状様相を示すことを確認している。

以上，ポリゴンまわりには約 $r / d=0.8$ を境界とし てその内側では角部の通過によるポリゴン辺ごとに対 応して形成される周期的かつ比較的安定した弧状の領 域, および外側では, 回転角度に無関係に不安定かつ 三次元的な流れの二つに大別することができる.

図 7 は図 4 に示した点線上に扔ける円盤, ポリゴン の周方向速度 $V_{\theta}$, 半径方向速度 $V_{r}$ の半径方向变化を 示す。ここに, 回転角度に無関係な 50 枚の瞬間速度 分布から算出された時間平均速度分布も併せて示して ある. 円盤の周方向速度 $V_{\theta}$ は平均, 瞬間ともに半径 


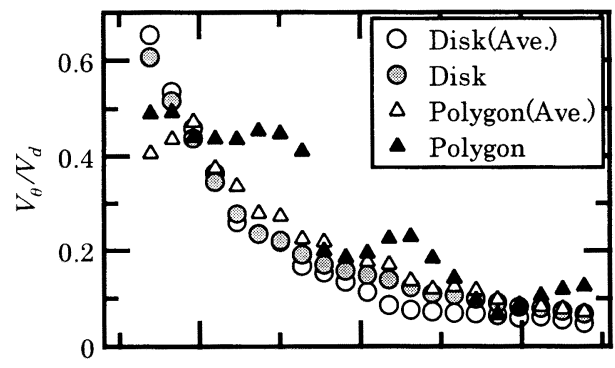

(a) $V_{\theta}$

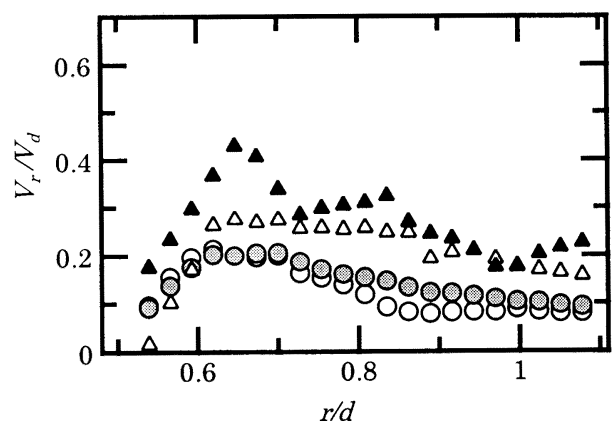

(b) $V_{r}$

Fig. 7 Average and instantaneous velocity profile $(500 \mathrm{rpm})$

方向になめらかに減衰する. 半径方向速度 $V_{r}$ は $r / d$ $=0.63$ 付近まで増加し, 半径の増加とともに緩やかに 減衰する。円盤の平均, 瞬間の $V_{\theta}, V_{r}$ は定性・定量 的に一致しており, 円盤回転に伴う流れはつねに図 4 の速度分布を有する定常流とみなせる．また， $r / d>$ 0.7 では $V_{\theta} / V_{r}$ はほぼ一定の值となることから，この 領域では自由旋回流となっていると考えられる。一 方，ポリゴンにおいて $V_{\theta}$ の時間平均分布は円盤のそ れとポリゴン近傍を除き一致しているが, 瞬間分布は, $r / d \geqq 0.6$ において, 時間平均分布と大きく異なり $r / d=0.6$ から 0.7 まで $V_{\theta} / V_{d}=0.4$ の大きな値を示 し,さらに $r / d=0.85$ に極大值をもつ階段状の特異な 分布となっている. 半径方向平均速度分布は, 円盤と 同様に，ポリゴン近傍の $r / d=0.63$ 付近に最大值を有 している. $r / d>0.63$ ではポリゴンは円盤に比し，全 領域にわたり半径方向平均速度は大きく, $r / d>0.8$ の外周域においても減衰することなく 0.2 程度の半径 方向速度を有している，また，ポリゴンの瞬間速度 $V_{r}$ は $r / d=0.65$ に卓越した最大值を有するとともに， $V_{\theta}$ と同様に $r / d>0.65$ では半径方向に階段状に減少 を示している。この階段状の速度変化は局所的に速度 の速い領域である弧状の領域に対応する。

図 8 は円盤およびポリゴンの回転角度 $\theta=33^{\circ}$ にお

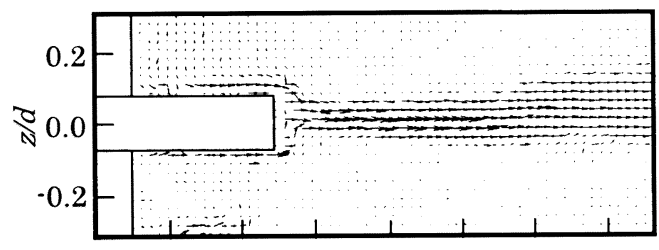

(a) Disk

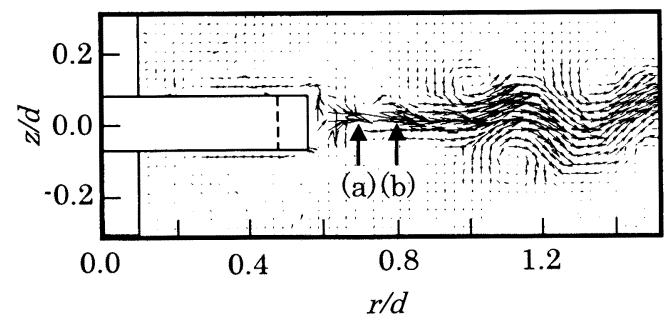

(b) Polygon $\left(\theta=33^{\circ}\right)$

Fig. 8 Instantaneous velocity vector map $(r-z$ plane $)$

ける $r-z$ 断面の瞬間速度ベクトルを示す。なお, 円 盤, ポリゴン $z$ 軸方向上下遠方では円盤, ポリゴン近 傍に比べきわめて小さい速度となることから，これら の近傍断面に着目して図示している. 円盤は， $z / d=0$ 軸に上下対称な速度分布となっており，半径方向成分 が支配的な分布となっている，また，円盤上下面上に は, 本計測の計測分解能ならびに近傍部の反射の影響 等から境界層の構造までは議論できないが, 半径方向 への流れが存在している。一方，ポリゴンは円盤同様 にポリゴン面上に半径方向の流れが存在し, $z / d=0$ 軸上では $r / d=0.7$ 近傍から上下の摇動を伴う半径方 向に向かう周囲に比べて速い流れが存在している。こ の流れの上下幅はポリゴン近傍においては円盤に比し 狭い. $r / d=0.8$ から 1.2 においては，徐々に幅を広 げ，その振幅はポリゴンの幅よりも大きくなり,さら に, 摇動流の外側の領域には上下交互に渦が形成され ている.この大きな渦構造は, 図示は割愛しているが 回転角度と無関係にさまざまな大きさ, 配置のものが 存在している.これらの摇動流および渦形成は, 図 $6(\mathrm{~b})(z / d=0.1)$ に示された局所的な速度の大小によ り形成されるまだら状の流れ構造に対応する.ポリゴ ンの回転角度と無関係に $r-z$ 断面に現れる摇動流や その上下の不規則な渦群は, 前述した $r-\theta$ 断面の $r / d$ $<0.8$ に現れる比較的安定した弧状の領域の流れ構造 が $r / d>0.8$ の外周域では複雑な流れ構造に変化する ことによる。また，高速回転(2000 rpm)する円盤に おいても,レイノルズ数増加に伴う変化により $r / d>$ 0.8 の領域にこのような摇動流に類似した流れ構造を 


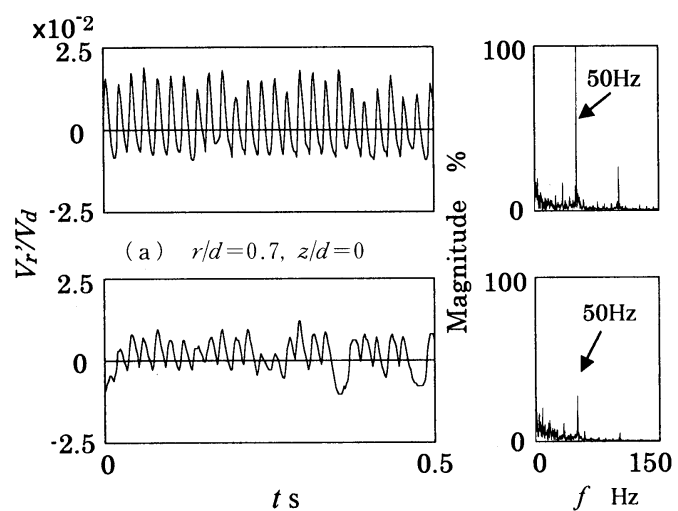

(b) $\quad r / d=0.8, z / d=0$

Fig. 9 Velocity wave and frequency spectrum

形成するが，ポリゴンのもつ弧状領域は現れないこと を確認している，以上の結果より，弧状の領域の干渉 や境界層の特性の変化により形成される摇動流はポリ ゴンが配置された容器内に大規模かつ複雑な流動を形 成し, ポリゴンに不規則な振動を誘起させ回転むらの 原因となっていると考えられる. 以降では, ポリゴン の辺に対応して周期的かつ比較的安定した流れ構造を 有するポリゴン近傍域 $r / d<0.8$ に着目し, その流れ 構造の生成機構を詳細に検討する.

$4 \cdot 2$ ポリゴンまわりの流れの詳細構造 図 9 は 図 3,8 に示した点 (a), (b)での LDV 計測による半 径方向変動速度 $V_{r}^{\prime}$ の波形と周波数分布を示す. $r-\theta$ 断面において弧状の領域が通過する点 $(\mathrm{a})(r / d=0.7)$ においては, 大振幅の周期性の強い波形を示し，これ らの周波数特性は $50 \mathrm{~Hz}$ に最大卓越周波数を有する ものとなっている.この周波数は, ポリゴンの角数と 回転数の積で表される角部通過回数の周波数と一致し ている。このことは，ポリゴンの角部ごとに形成され る弧状の領域がこの周波数で通過していることを意味 している.さらに前述した騒音特性が同様の周波数特 性を有することから，この弧状の領域と流体騒音発生 に相関があるとみられる. 次に, 図 8 に示された $r-z$ 断面の上下摇動流が始まる点 $(\mathrm{b})(r / d=0.8)$ では, 点 (a ) に類似した $50 \mathrm{~Hz}$ の周期的な変動波形を有し ているが, 変動波形の振幅は点 $(\mathrm{a})$ のそれに比べ小さ くなっている. 加えて, 波形は長周期的な摇動も含ま れ，その周波数特性は $8 \mathrm{~Hz}$ 程度のものとなっている. これらの低周波数の変動は前述した回転むらなどの原 因と考えられる摇動流の変動に対応しているといえ る.

図 10 は上述の周期性の強い流れ構造を各回転角度

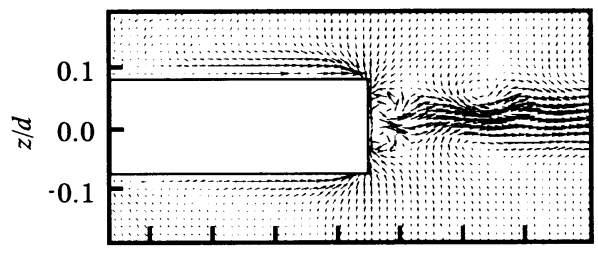

(a) $\theta=15^{\circ}$
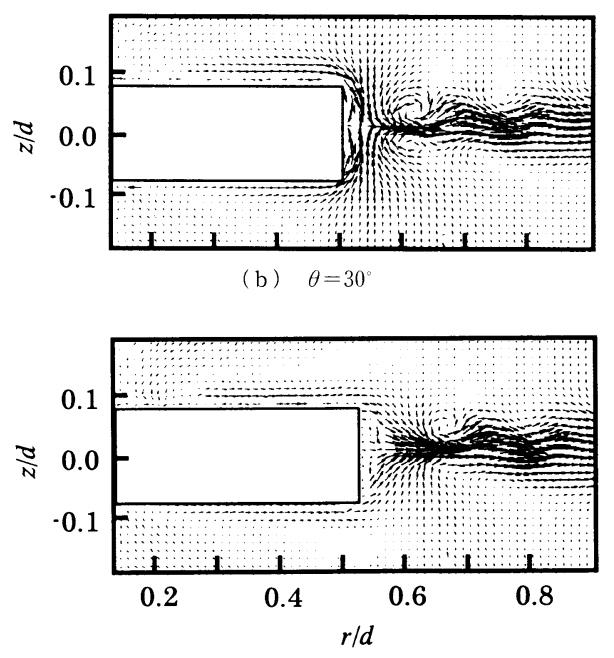

(c) $\theta=45^{\circ}$

Fig. 10 Phase average velocity vector map ( $r-z$ plane $)$

ごとの $r-z$ 断面におけるポリゴン近傍速度べクトル にて示す.ここに, 各回転角度の 50 枚の瞬間速度を

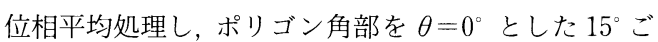
との分布 $(\mathrm{a}) \sim(\mathrm{c})$ を示している. 図 10 ( a ) $\theta=15^{\circ}$ ではポリゴン上下表面から鏡面部へと流れ込む流れが あり，これらが鏡面部近傍域に上下対称の二つの渦対 を形成している.さらに，この渦対間には半径方向へ の流れが存在し，この流れは図 4(b)に示された弧状 の領域に対応している. また, 図 8 の摇動流ほど大振 幅ではないが半径方向流れの上下の摇動も現れてい る。これがさらに増幅し, 外周域において前述した摇 動流へと発達すると考えられる. 図 10 (b ) $\theta=30^{\circ}$ で は, (a )の鏡面部近傍の渦対の中心は半径方向へと移 動し,（c） $\theta=45^{\circ}$ では, さらに渦対中心が半径方向 に移動している. 以上の結果は, 角部の通過ごとに $\theta=15 \sim 30^{\circ}$ 間で渦対が形成を開始し，その渦対間に 弧状の領域を伴いながら, 渦対は $\theta$ の増加とともに半 径方向に旋回しつつ移動するといえる。

図 11 は各回転角度の $r-z$ 断面におけるポリゴン近 傍渦度分布を示す. 無次元渦度は位相平均処理された 


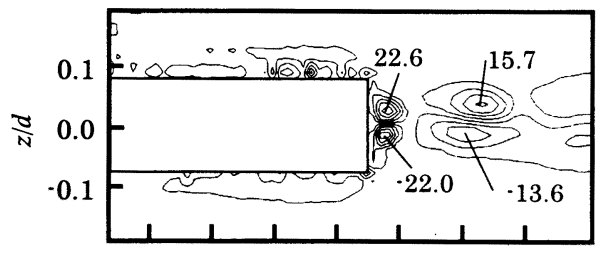

(a) $\theta=15$

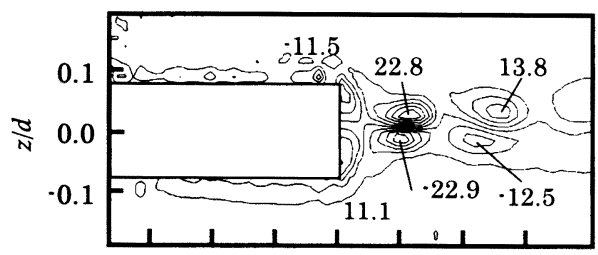

(b) $\theta=30^{\circ}$

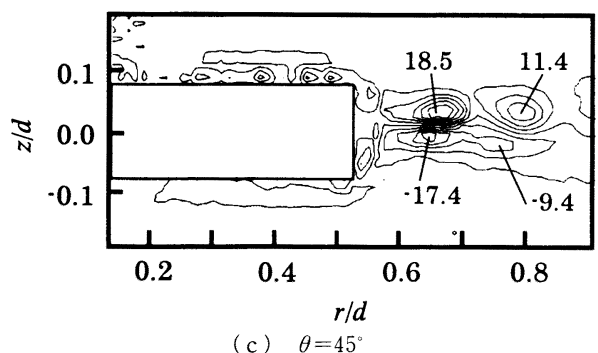

Fig. 11 Vorticity map $(r-z$ plane $)$

$r-z$ 断面速度分布から算出されたものであり, 反時計 回りを正としている. 図 11 ( a ) $\theta=15^{\circ}$ ではポリゴン 極近傍にベクトル分布において示された渦対に対応し て正負の強い渦度が集中している. また, その外周に 別の正負の渦対が存在し, その強さは極近傍の渦対に 比し小さい.この渦対は一つの上流側の辺において形 成された渦対がこの領域に旋回してきたものである. 図 11 ( b ) $\theta=30^{\circ}$ では近傍の渦対の中心は半径方向へ と移動し, その渦度は ( a ) に比し 1４\%大きくなって いる.また, ポリゴン極近傍には上下からの流れ込み によって示される二次的な渦度が形成されている. 外 周の渦対は図 11 ( a ) に比し 10\%程度渦度を拡散させ 半径方向に中心を移動させている. 図 11 ( c ) $\theta=45^{\circ}$ では, 近傍の渦対の渦度中心はさらに半径方向に移動 し, 渦度は $80 \%$ 程度となり拡散を始めている。この渦 対がさらに半径方向に移動し, 渦度を減衰し, 図 11 (a)の外周側の渦対となる.

図 12 は回転するポリゴンの上面近傍 $z / d=0.1$ の $r-\theta$ 断面の速度ベクトルである. 図 12 中点線部へ左 右から流れ込む流れが示されている.この領域では $V_{z}$ 成分も含む複雑な三次元構造を有する流れが形成

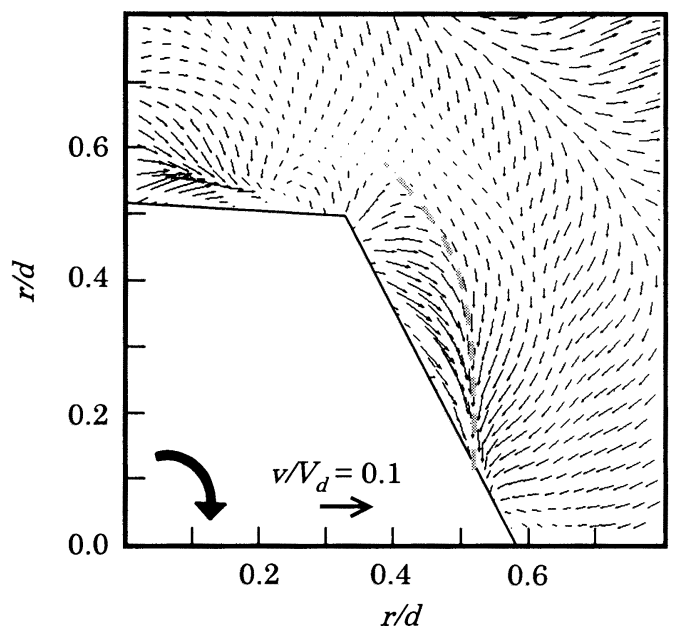

Fig. 12 Phase average velocity vector map $(r-\theta$ plane, $z / d=0.1)$

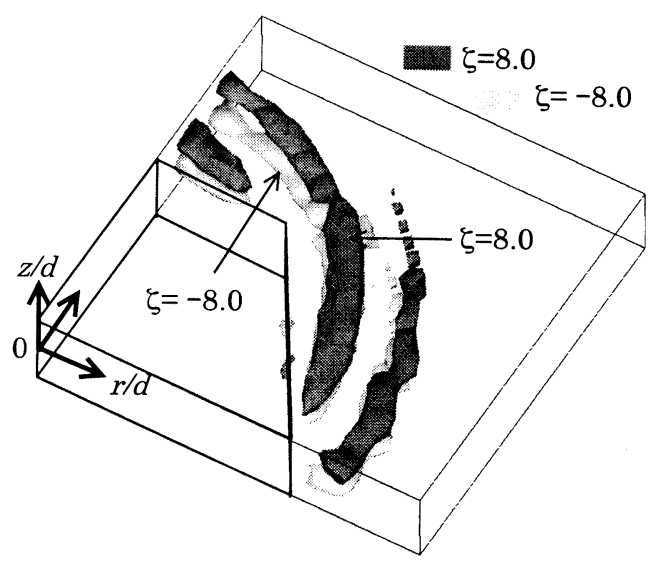

(a) Perspective view

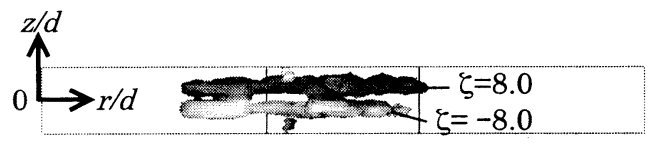

(b) Side view

Fig. 13 Vorticity isosurface

されていると考えられ，図 9 の $r-z$ 断面の分布から, 渦対の構造と対応して存在している. さらに, この点 線の始点すなわち渦対形成開始点となるポリゴン鏡面 部に, 全領域から流れが集中している.このことは, この位置においてポリゴン鏡面中央部へ向かう $z$ 軸 方向の流れが形成されていることを意味しており，こ の流れは渦対形成の要因となる. また, ポリゴン鏡面 に形成される曇り領域は, この流れと回転方向上流側 角部の間に形成されている。このことは, この流れに 
より供給される環境中の浮遊物質が取り込まれ, 化学 的および熱的要因によりこの領域に凝着すると考えら れる。

図 13 は図 10 の $r-z$ 断面における渦度分布をさら に詳細に $3^{\circ} こ ゙ と に$ 求め, 全領域において再構築した 無次元渦度等値面の準三次元立体表示である. 全体像 ( a ) と側面像 (b) を示しており, 渦度の正負を色の濃 淡で表現している。これより，ポリゴン近傍を開始点 としてポリゴンまわりを旋回する一対の渦管が形成さ れていることが明りょうに示されている．前述のとお り, $r-\theta$ 断面に示された騒音特性と同様の周波数特性 を有する弧状の領域に対応し上下に形成される渦管構 造が存在しており, 騒音はこれらが複雑に干渉するこ とや，ポリゴンや周囲壁などの物体と相互に干渉する ことで発生すると考えられる。また，これらの渦管は ポリゴン極近傍ではほぼ上下対称であるが，ポリゴン から離れた領域においては, 渦管同士が相互干渉, あ るいは伸縮・合体することによって, $r-z$ 断面の $r / d>0.8$ の外周域の摇動流や不規則な渦構造など, 複雑な流れ構造に変化するとみることができる.

以上のポリゴン固有の流れ構造の生成を抑制するこ とにより,ポリゴンまわりの騒音や鏡面の曇り, 回転 のむらなどの問題を解決することが期待できる.

\section{5. 結 言}

回転するポリゴンミラーまわりの流れに関して, 各 断面に拈ける二次元 PIV 計測と, 詳細な速度情報を 得るための LDV 計測を併用し, 回転円盤とポリゴン ミラーの流れ構造を比較検討した. さらにポリゴン近 傍部に着目することにより, ポリゴンミラー固有の流
れ構造を明らかにし, 以下の結果を得た。

（1）回転するポリゴンミラーまわりには円盤まわ りの流れと大きく異なり, 角部の存在によりポリゴン 近傍の弧状の速い速度領域を伴う一対の渦管形成域, およびその外周方向に広がる摇動流とその上下に不規 則に形成される大きな渦構造域の二つの特徵的な流れ 構造が形成される。

（2）ポリゴン極近傍角部通過ごとに形成される一 対の渦管の形成は, ポリゴンの角数と回転数の積で表 される角部通過回数の周波数を有する流体騒音の原因 となる.また，これらの渦管形成開始点の回転角 $\theta=$ 15～30 の鏡面部に集中した三次元的な流れ込みがあ り，この流れが鏡面の曇りを誘引するといえる.

（3）一対の渦管の外周域では，これらの渦管が相 互干渉, 伸縮・合体するため, 摇動流および不規則な 渦構造に変化する.これらの流れが, ポリゴンミラー の回転むらなどの要因となるといえる。

\section{文献}

（1）太田浩之・丈田雅也，スキャナモー夕音に関する研究，機 論, 65-639, C (1999), 4564-4571.

（2）大久保信行・片岡宏之・中山司，実験㧍よび数值計算を 用いた高速回転体の騒音解析および低騒音化，機論，58 549, C (1992), 1406-1410.

(3) Obara, H., Nishimura, D., Goto, T., Kaneko, K., Horikoshi S. and Matsudaira Y., Flow Structure Around a Rotating Polygon Mirror, Proc. 5th. JSMEKSME Fluids Eng. Con., (2002), 152.

(4) Reed, H. L. and Saric, W. S., Stability of Three-Dimensional Boundary Layers, Ann. Rev. Fluid Mech., 21 (1989), 235-284.

(5) Saric, W. S., Reed, H. L. and White, E. B., Stability and Transition of Three-Dimensional Boundary Layers, Ann. Rev. Fluid Mech., 35 (2003), 413-440. 